\title{
ANALYSIS OF LEASING ADVANTAGES AND DISADVANTAGES AS PUBLIC-PRIVATE PARTNERSHIP'S FORM IN ROAD INFRASTRUCTURE PROJECTS
}

\author{
Komissarova V.V., Lecturer \\ Vladivostok State University of Economics and Service, Vladivostok, Russia \\ E-mail: valeriya.komissarova@vvsu.ru
}

\begin{abstract}
The article deals with the problem of road infrastructure. The road network development gives the economy new production capacity by reducing transportation costs and transportation time expenditure, therefore, improving the quality of roads significantly affects the price level in the country, that means the common weal, the value of service and the increase of GDP, and as a consequence, on the amount of charged taxes. In order to ensure a sustainable growth of the common weal, the mutually connected development of the economy and the road transport complex is necessary, but now the state of the industry is characterized by a number of problems.
\end{abstract}

\section{KEY WORDS}

Road infrastructure, financing, leasing, innovation, public-private partnership (PPP), roads, transport infrastructure, concessions, credit.

Today the issues about the road network development are priority in Russia that is confirmed by the regulatory documents of the Ministry of Transport of the Russian Federation and defined in the Transport Strategy of the Russian Federation for the period until 2030 [1]. The most actual questions are about development of transport and, therefore, road industry at the regional levels. In many aspects roads determine the opportunities for the development of regions taking into account their geopolitical situation, mass transportation of goods and passengers is carried out, and life becomes impossible without the transport arteries, even small settlements, not to mention of large cities.

The road network development gives the economy new production capacity by reducing transportation costs and transportation time expenditure, therefore, improving the quality of roads significantly affects the price level in the country, that means the common weal, the value of service and the increase of GDP, and as a consequence, on the amount of charged taxes. Mentioned directions presuppose the development of measures to improve the activities of road enterprises, including the improvement of the management structure and monitoring system for the transport and operational status and development of the road network, the formation of a financing system based on program-target and project approaches, the training of highly qualified specialists and many other tasks to develop the road economy.

In the furtherance of these goals, the state's primary targets are to increase the reliability and operation life of road facilities, increase the technical level and transportoperational condition of highways, reduce the cost of road works, reduce accident rates and improve environmental safety on roads, etc. At the same time, the quantity and quality of transport communications serves are as an indicator of successful economic development and scientific and technical progress of the country. The state of the road economy is of strategic importance for the development of macroeconomic relationships not only between the regions of Russia but other countries.

In the project «Fundamentals of the Road Reform Concept of the Russian Federation», the road economy of the Russian Federation is defined as an element of the transport infrastructure that provides constitutional guarantees of citizens for freedom of movement and makes possible the free movement of goods and services, while the territorial integrity and unity of the economic space of the Russian Federation is determined by availability and condition of the road network for common use [2]. 
In order to ensure a sustainable growth of the common weal, the mutually connected development of the economy and the road transport complex is necessary, but now the state of the industry is characterized by a number of problems.

Firstly, this is a lack of financing of road maintenance operations, which leads to a shortening of the road operation life, an increase in the need for maintenance and repair costs. This is due to the fact that the modernization and development of the road network require significant capital investment, but the high capital intensity of road facilities and long payback periods hamper private investment.

Secondly, the simultaneous increase of the load on the road network exacerbates the inconsistency of highways to regulatory requirements for vehicle operation indicators.

Thirdly, 34 automobile routes of the European and Asian network of international highways pass through the territory of the Russian Federation. Over the past 20 years, the percent of transit traffic has increased from $12 \%$ to $30 \%$ of the total traffic flow. In the conditions of the globalization of the world economy and the development of foreign economic relations, the territory of the Russian Federation may find itself in economic isolation because of the lag in the development of the road network, its inadequacy to international requirements, the lack of development of a network of expressways allowing the crossing of the whole country without delays [3].

The unsettledness of the above-mentioned problems leads to the fact that the roads are one of the limitations which restrain the country's economic growth and reduce the competitiveness of the Russian economy. The growing lag in the development of roads leads to significant economic losses in agriculture, losses from road accidents and the negative impact of the road and road complex on the environment. The annual amount of losses associated with the inadequate development of the road network to the needs of the national economy and the low technical operation of the road sector is estimated at about 1.8 trillion rubles, which exceeds 3\% of Russia's GDP and affects the receipt of taxes to the state budget [2].

Insufficient growth rates and low transport-operational indicators of the state of highways are due to factors such as insufficient funding for road maintenance; using of obsolete equipment and technologies; low quality of basic road building materials (crushed stone, bitumen, etc.) and structures; insufficient performance and technological discipline, etc. These reasons are aggravated by the inconsistency of the existing management systems in the road sector to the requirements of the development of the modern economy. At the same time, the improvement of management mechanisms can be viewed not only from the point of view of the necessary condition for the effective functioning of the road economy of the country, but also as a catalyst for the development of related sectors of the economy, a powerful factor in the formation of multiplicative effects, the forms whose manifestations are the growing competitiveness of potential stakeholders and increasing tax revenues to the budget state.

Today the fleet of vehicles is characterized by heavy wear and a relatively small number of modern machinery and equipment capable to provide qualitative indicators of construction, repair and maintenance of roads, which depend on the technical level of the machinery itself and the degree of automation. Wear of the equipment and machinery fleet in the road economy reached a threshold level and exceeded $50 \%$ at a sevenfold decrease in the renewal ratio of fixed assets since 1994. So the specific weight of machines with expired operation life to of the end of 2009 was: for crawler cranes - about $70 \%$, for tower cranes $58 \%$, for tractors $-56 \%$. The unsatisfactory technical condition of most of the Russian roads is a powerful incentive for the speedy renewal of fixed assets in the road sector [4].

Over the years, we have the goal to achieve not only sufficient amounts of road construction, but also to improve financing mechanisms in parallel with changes in management in the road sector. This implies the application of a new approach to investment with a view to the technical re-equipment of the road industry enterprises.

Speaking about the innovative potential and the implementation of innovative projects capable to ensure the competitiveness of the Russian economy, it is necessary to understand with the aid of which modern financing instruments innovation will be 
implemented to solve the problems of the transport complex development in the Russian Federation.

To ensure the financing of road facilities, it is efficient to create sources of stable cash receipts in the road sector. On the one hand, this is possible due to the creation of trust funds, which would be formed of revenues from the payment of excises for fuel and lubricants, transport tax and other revenues from the exploitation and using of motor roads, on the other hand, through the using of mechanisms of public-private partnership (PPP), where private investment would become one of the main sources of funding for technical upgrading of the road sector.

Studying the experience of developed and rapidly developing countries, the changes can be traced in such industries as road and utilities, rail and pipeline transport, electricity, ports, airports, previously completely state-owned and evaluated as a cardinal. The reason for these changes is, on the one hand, the fact that a lack of funds was appeared in the state budgets not only for further development, but also for simple maintenance of effective functioning of these industries and, on the other hand, the impossibility of privatization because of their strategic, social and socio-political significance. This contradiction served as the basis for creating and implementing the concept of public-private partnership (PPP) in business practice.

Despite the fact that today in Russia, public-private partnership, from a legal point of view, can only be exercised on the basis of the law on concessions, this kind of partnership may act in such forms as governmental contracts, rent, financial rent (leasing), public-private ventures, production sharing agreements, concession agreements [4].

The main features determining PPPs include, firstly, that the goal of this cooperation is the national and international socially significant projects implementation in various fields of activity based on the state and business structures interaction for a long-term basis, and secondly, the public-private partnership principle is based on the pooling of resources and the distribution of risks among participants [5].

In a broad sense, the most diverse interaction forms between business and power structures can be attributed to the basic PPP forms - from creating charity funds to subsidizing the real sector of the economy. In practice, a narrower approach is often used when PPP is understood as an equitable, mutually beneficial cooperation between the state and private business in the process of building public infrastructure and providing public services, subject to the sharing of risks and responsibilities [5].

The main spheres of PPP application are, first of all, those that traditionally belong to the state jurisdiction, for example, public goods (transport, communal, social infrastructure, cultural objects); public services (maintenance of public facilities, housing and communal services); objects of ecological sphere; law enforcement services; objects of social sphere (education, health, social protection).

At the same time, this system of relations causes many disputes among scientists and practitioners. To date, there is no specific definition, no single understanding of the essence of public-private partnership. Thus, some experts consider PPP as a form of indirect privatization on the grounds that the advanced economies experience often indicates a redistribution of powers between the state and private business, with the broad powers transfer, related to the ownership, operation, construction and financing of facilities. In this case, cases of subsequent partial or complete privatization of such objects are not uncommon.

Other scientists consider PPP as a special, full-fledged form of state facilities privatization replacement, which allows, on the one hand, to realize the entrepreneurial initiative potential of private capital, on the other hand, to retain state's control functions in socially significant sectors of the economy. At the same time, the state remains the owner of the objects, attracting private capital to solve a variety of problems [6].

In connection with the existing contradictions in Russia, it is necessary to develop its own strategy for applying public-private partnerships with a unified PPP project management system, including regulatory support, financing mechanisms for various options for interaction between the state and private business, providing privileges and guarantees to 
private investors, training specialists to work in this area, the distribution of risks between partners in partnerships.

In modern conditions of reforming the domestic economy, the study of the processes of development and regulation of forms of financing investment projects is an actual direction. Along with such methods of financing as credit and budget financing, self-financing, corporatization, leasing became widespread and applied, which creates additional competition in the financial services market due to its dual nature: on the one hand, it is a kind of capital investment, since it involves investing in material assets in order to generate income, on the other hand, it preserves the features of the loan, since it is provided on the basis of pay, urgency, and repayment. In emerging economies, leasing often becomes an alternative to bank lending for the acquisition of fixed assets, thereby allowing companies not to increase their debt to the bank, i.e. is an additional form of long-term financing. This is particularly important in the current structure of liabilities of Russian banks, which does not allow to direct attracted financial resources into long-term projects related to the road sector.

Structural reorganization of the domestic economy is impossible without significant activation of investment processes in various areas of economic activity. Under the existing conditions, leasing, as an alternative to direct investment, on the one hand, and the form of public-private partnership, on the other, is an effective financial tool that can help quickly use the achievements of scientific and technological progress in the construction, repair and further maintenance of roads.

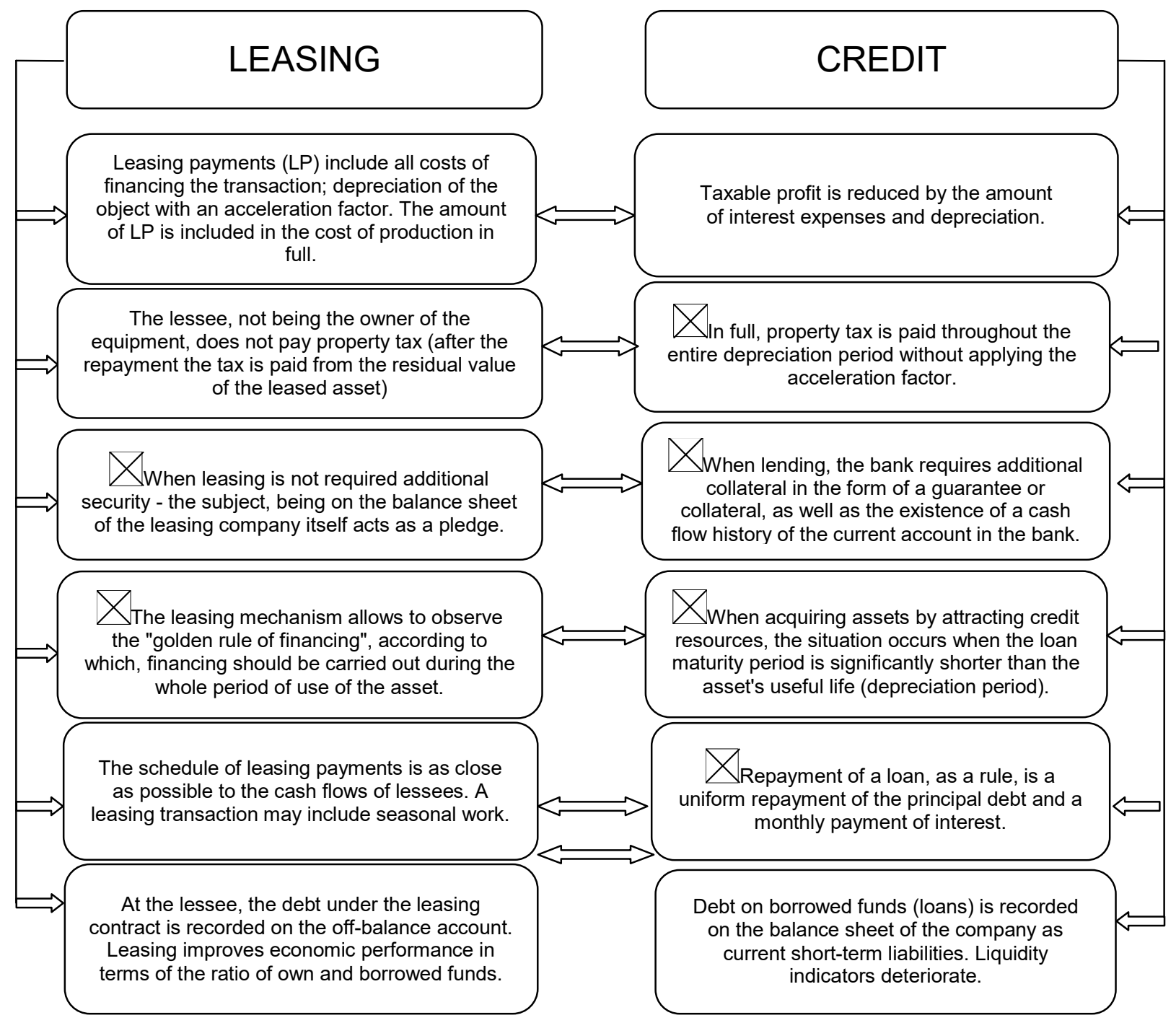

Figure 1 -Comparing the leasing and credit 
When acquiring fixed assets from enterprises, as a rule, there is a choice between buying a fixed asset at the expense of a bank loan and acquiring it in leasing. The economic efficiency of leasing for a lessee is the possibility of using tax advantages. First of all, it is an opportunity to include leasing payments in the cost of production, which reduces the profit tax, as well as the ability to apply accelerated depreciation of the leased asset, which reduces the property tax. The advantages of using leasing in comparison with bank lending are shown in table 1.

The leasing importance for economic development lies in its ability to be an effective financial instrument for acquiring and updating fixed small and medium-sized enterprises assets, as well as for financing multimillion-dollar transactions in transport (for example, leasing of road machinery, aircraft), oil production (leasing drilling installations), etc. To date, a significant part of all leasing transactions in Russia are transactions on road transport, rail transport, road construction equipment, aircraft engineering, power equipment, as well as equipment intended for mining (Figure 2).

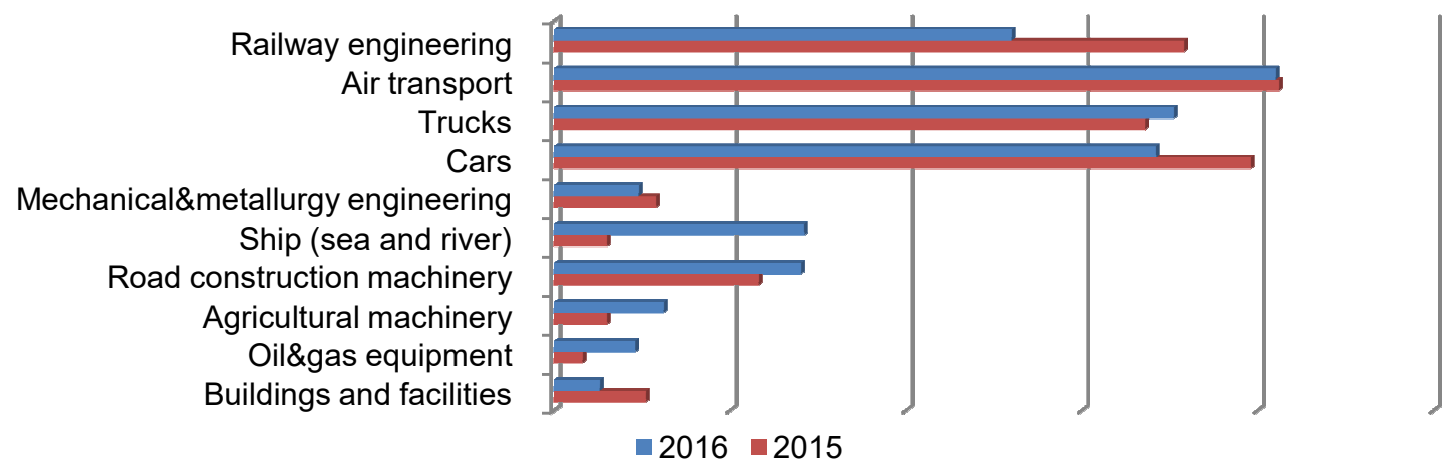

Source: compiled by the author according to "Expert RA».

Figure 2 - Key market segments share in the new business [7]

Leasing helps to sell equipment. With the advent of leasing for the equipment manufacturing companies, new sales opportunities for their products have been opened. Many foreign firms use the mechanism of international leasing when delivering their equipment to customers.

The main leasing operations advantage is that enterprises are able to modernize or increase their fixed assets without realizing adequate one-time capital investments, either from own funds or from borrowed funds.

For the enterprises of the road economy, the leasing mechanisms attractiveness is explained by the fact that the purchase of machinery and equipment reduces the need for own starting capital, that is, one does not have to pay for the necessary equipment, which frees the user's liquid funds, increases working capital to expand production and without a sharp financial strain allows you to update fixed assets. Also, leasing allows to observe the "golden rule of financing", according to which the period of external financing should correspond to the period of use of the asset.

The choice of using leasing as one of the mechanisms for updating the fixed assets of road enterprises can be dictated by the fact that it is a procedure for raising borrowed funds in the form of a long-term loan provided in kind and repaid in installments, has established itself as an effective mechanism for attracting investments in road construction and the sphere of road maintenance, housing and communal services and passenger communication.

Taking into account the fact that the introduction of innovative technologies and equipment in road construction through the use of preferential leasing mechanisms is a form of state support for domestic manufacturers of machinery and materials for which there are wide opportunities for the sale of products, the importance of positive aspects inherent in leasing transactions in the sphere construction, repair and maintenance of roads. 
The advantages of acquiring road-building machinery for road enterprises under leasing agreements are: attributing leasing payments to the cost of production and work, which leads to a reduction in the taxable base (taxes on profits and on property); use of accelerated depreciation, which increases the possibility of prompt updating of obsolete equipment and technical re-equipment of production. At the same time, the term of the leasing agreement is much less than the standard operating life of the property and the client does not pay the property tax in full due to accelerated depreciation; VAT on the leasing agreement is fully set off; the debt under the leasing contract is accounted for on off-balance accounts and does not worsen the liquidity indicators of road enterprises in terms of the ratio of own and borrowed funds; the system of leasing payments flexibility is ensured: a delay in the first payment, a gradual increase or decrease in payments, an orientation to seasonality of work is possible, which is quite important for road enterprises; the risk decreases when developing innovative products: in case of insufficient demand, it is possible to return the leased property to the lessor (in case of using operational leasing), which is also an important factor for the road industry enterprises.

Should note the economic and social effect of the implementation of preferential leasing programs: providing with workplaces for about 6 thousand people; reduction of harmful substances emissions into the atmosphere due to the using in the supplied equipment of modern engines that comply with the ecological standard "EURO-3 and above"; an increase in the receipt of taxes in the Russian Federation budget for more than 2 billion rubles [8].

Despite of the obvious advantages of using leasing, organizations involved in the maintenance and operation of highways are not actively updating their machinery through leasing contracts. The reasons for this lie in the insufficient financing of repair and maintenance of highways; participation in the repair and maintenance of roads of enterprises that won the auction, but do not have a sufficient set of equipment and qualified specialists; decisions to purchase imported equipment because of low consumer qualities of domestic, etc. The latter circumstance should be paid special attention. For 10 years, the share of equipment of Russian manufacturers by main types has decreased more than 2 times, while domestic production technology is in demand due to the relatively low cost and the presence of an extensive service network. On the sum of consumer properties, such as price and quality, after-sales service, it is not a leader in the Russian market, and if the approaches to the quality of production and maintenance of machinery are not revised, domestic producers will be forced out of the market by foreign competitors.

Also, in order to attract extra budgetary funding and improve the road management system, significant changes have been made to the legislation. The federal law «About Roads and Road Activity in the Russian Federation and on Amending Certain Legislative Acts of the Russian Federation» [9], aimed at regulating relations in the use of highways, including on a fee basis, was adopted; the federal law «About the State Company Russian Highways» [10], the main purpose of which is trust management of federal roads transferred to it; creation of the State Transport Leasing Company and the Investment Fund.

Based on the above mentioned issues, we can note that an important task for the further development and application of leasing, as a form of funding for technical reequipment of road enterprises, is to legitimize the benefits provided by the Law on Leasing and remove legislative barriers that impede the development of leasing. It is necessary to take into account and critically evaluate all provisions of the current legislation aimed at providing leasing with advantages in the field of regulating economic activity, especially the advantages associated with taxation, customs and currency regulation. Along with this, it is necessary to overcome numerous difficulties, so that leasing schemes work efficiently, according to the laws of the market. For this, it is necessary to develop not only financial, but also operational leasing, as well as a set of accompanying and additional after-sales services; Using of leasing schemes with flexible schedules of leasing payments and seasonal adjustment; improvement of mechanisms of state financing of leasing operations at reduced rates, etc. 
Conclusion. The problems of road economy development discussed in the article and the using of leasing as a form of financing projects for the technical re-equipment of the road sector make it possible to conclude that the enterprises which build, maintain and repair roads need appropriate conditions for the successful development of the industry. These conditions can be ensured by the interconnection of infrastructure elements in the banking system and the system of relations between state and market mechanisms. In this regard, we believe that to further the effective operation of the industry, it is necessary to introduce forms of public-private partnership, which has become one of the main instruments of public administration in the world. The events of the last decade and a half have definitely shown that integration of the economic potential of private entrepreneurship and the state's possibilities is necessary to solve the most complicated socioeconomic, structural, technological and other strategic tasks of Russia's development, to realize its national interests and to ensure an enabling environment for life activity. The advantages of using PPP forms are obvious, therefore, the accelerated creation of a legal basis for wider use of leasing schemes and other forms of public-private partnership in which partnership with the private sector can bring great benefits through effective quality of service, while allowing the authorities to legislate distribution rights, responsibilities and risks between the state and the investor in the implementation of various transport projects.

\section{REFERENCES}

1. «Transport Strategy of the Russian Federation for the period up to 2030 » order dated November 22, 2008 No. 1734-r / Official site of the Federal Agency for Federal Property Management Rosavtodor, 2011.

2. The project «Fundamentals of the concept of reforming the road economy of the Russian Federation» [Electronic resource] / Official website of the Federal Agency for the Roads «Rosavtodor», 2013. - Access mode:

3. http://rosavtodor.ru/information.php?id=100

4. Information and analytical materials for the meeting of the Public Council under the Ministry of Transport of the Russian Federation on the issue «The state and prospects of the public net-work roads development» [Electronic resource] / Ministry of Transport of the Russian Federation, 2010. - Mode of access: https://www.mintrans.ru

5. Marketing research of the Russian market of construction and road machinery by Global Reach Consulting [Electronic resource]. Access mode: http://marketing.rbc.ru/

6. Chonka A. Public-private partnership: symbiosis of the state and business [Electronic resource] / Legal portal «Arkon», 2010. - Access mode: http://arkongroup.ru/see.php?see $=56$

7. Bondar N.N. Experience of public-private partnership in the transport sector: achievements and setbacks. [Electronic resource] / Legal portal «Arkon», 2012. - Access mode: http://arkon-group.ru/see.php?see $=53$

8. R. Romanovsky «The leasing market for the 2016» [Electronic resource] / Rating agency Expert RA, 2016. - Mode of access: https://raexpert.ru/researches/leasing/2016/part1

9. Sadykov V.V. "Evaluation of the efficiency of renewal of the technical park of road enterprises with the use of the leasing mechanism: the results of 2010» [Electronic resource]. Access mode: http://rosavtodor.ru/shownews/

10. Federal Law «About Roads and Road Activities in the Russian Federation and on Amending Certain Legislative Acts of the Russian Federation» No. 257-FZ of 08.11.2007 [Electronic resource]. Access mode: http://rosavtodor.ru/docs/

11. Federal Law «About State Company Russian Highways and on Amendments to Certain Legislative Acts of the Russian Federation» No. 145-FZ of July 17, 2009 [Electronic resource]. Access mode: http://rosavtodor.ru/docs/Osnovnye_dokumenty/ 